\title{
Impact Assessment for Sustainable Project Management And Pension Funds Projects Performance In Kenya
}

\author{
Olive M. Gitau, Dr. Paul K. Sang \\ Institution Kenyatta University
}

\begin{abstract}
Sustainability is an evolving area of research and is grabbing the attention of corporations, research communities, and regulatory bodies worldwide which had enhanced its implementation. The prevailing trend towards economic growth in developing countries has resulted in a huge demand for delivering construction projects which in turn has overshadowed sustainability concerns. Consequently, project managers in developing countries are lagging in embracing the concept of sustainability in managing projects. Specific focus has been given to construction projects in the pension industry in Kenya. To address this challenge, the paper explored sustainable project management based on a comprehensive literature review through a desk review of numerous academic journal articles to evaluate pension funds projects performance. The literature showed that to enhance projects performance, the pension funds need to implement sustainable project management, specifically, environmental and social impact assessments with a focus on sustainability goals. Three theories were used to provide a foundation for the sustainable project management practices: stakeholder theory, the Triple Bottom Line (3BL) concept which captures the essence of sustainability and theory of risk management. The study established that current project management practices of Kenyan Pension Funds do not always ensure project success that secure desired market returns on these investments. As the pension schemes are also expected to continue to invest in alternative assets given the broadening of the allowable investment categories and to take advantage of the public infrastructural projects under the big four agenda (RBA, 2021), it becomes paramount to identify and implement sustainable project management practices for performance of the pension funds projects. The outcome of this research showed that sustainability goals and environmental and social impact assessment contribute towards pension funds projects performance. The moderating effect of the regulatory framework was determined to be supportive towards sustainable pension funds projects performance.
\end{abstract}

Keywords: Sustainable project management, impact assessment, pension funds, stakeholder management, project risk management, project performance

\subsection{Introduction}

Our current usage of natural resources cannot be considered sustainable. Development towards a sustainable society therefore requires change. The United Nations World Commission on Environment and Development already concluded that "In essence, sustainable development is a process of change in which the exploitation of resources, the direction of investments, the orientation of technological development and institutional change are all in harmony and enhance both current and future potential to meet human needs and aspirations" (World Commission on Environment and Development, WCED, 1987).

Sustainability is an evolving area of research and is grabbing the attention of corporations, research communities, and regulatory bodies worldwide which had enhanced its implementation (Olawumi and Chan, 2018). The prevailing trend towards economic growth in developing countries has resulted in a huge demand for delivering construction projects (Zhang et al., 2014), which in turn has overshadowed sustainability concerns (Chang et al., 2016). Consequently, project managers in developing countries are lagging in embracing the concept of sustainability in managing projects (Abidin and Pasquire, 2007). Yet, sustainable 
construction has become the new 'Zeitgeist' in recent years (Zhang et al., 2014) with project managers worldwide including in developing countries being expected to deliver projects in a sustainable manner (Dobrovolskienè and Tamošiūnienè, 2016; Du Plessis, 2007; Ortiz et al., 2009).

To address such a challenge, Silvius et al. (2012) outlined the principles of sustainability to be integrated into practices of project management. The concept of corporate sustainability refers to the ability of an organisation in using their limited resources effectively and efficiently over time in which waste is deliberately reduced, and best practices are implemented. It is comprised of three dimensions, economic, environmental, and social sustainability - the Triple Bottom Line (3BL) concept which captures the essence of sustainability (Savitz, 2006).

The temporary nature of projects is not logically compatible with the concepts of sustainable development, with its focus on long term horizons (Silvius et al., 2012: 30). The relation is made by the notion that projects initiate investments and deliver products or services (Weninger and Huemann, 2013). In fact, the relation between sustainability development and projects is often considered on the content side, related to the definition of the product or deliverable of the project. In addition, there is the process or delivery of the project (Gareis et al., 2013). This dichotomy of sustainability by the project and sustainability of the project, is a recurring theme in studies on project management and sustainability (for example Silvius and Schipper, 2015).

Labuschagne and Brent (2005) suggest that as the deliverable of a project is also shaped by the delivery process, the process and deliverable interact. Considering sustainable development principles in project management therefore requires considering not only the project life cycle, but also the life cycle of the deliverable of the project, and the artefacts this asset makes. Based on these interacting life cycles, Silvius et al. (2017) conclude that 'Sustainable Project Management' implies an "enlarged scope" of the project.

Applying the Triple Bottom Line in project management implies including environmental and social criteria, next to economic ones, in the evaluation of the business case of the project (Weninger and Huemann, 2013), the specification of the deliverables (Silvius and Schipper, 2014), the recognition of stakeholders (Eskerod and Huemann, 2013) and the assessment of risks (Huemann and Ringhofer, 2016). Eskerod and Huemann (2013) link sustainable development, projects and the role of stakeholders, and conclude that there is a need "to incorporating stakeholders and their interests in more project management activities."

Silvius and Schipper (2014) suggest "Sustainable Project Management is the planning, monitoring and controlling of project delivery and support processes, with consideration of the environmental, economic and social aspects of the life-cycle of the project's resources, processes, deliverables and effects, aimed at realizing benefits for stakeholders, and performed in a transparent, fair and ethical way that includes proactive stakeholder participation."

In Kenya, the retirement benefits assets under management stood at Kshs. 1,398.95 billion in December 2020. Immovable property accounted for 17.96 percent, equivalent to Kshs. 251.27 billion (RBA, 2021). This is the subject of focus of this study in determining the sustainable project management practices when investing these funds for performance of the pension funds projects. The Retirement Benefits Act 3 of 1997, section 37 states that every scheme shall have a prudent investment policy on the investment of the funds of the scheme so as to maintain the capital funds of the scheme and generally to secure market rates of return on such investment. This is the basis of pension funds engaging in various projects to secure market rates of return for its members within the asset classes allowable by the Retirement Benefits Authority (RBA).

\subsection{Problem Statement}

Emerging sustainability issues, such as the threat of climate change, over population, and the emergence of unpredictable sustainability risks, continuously affect sustainable growth (Bui \& de Villiers, 2017). Sustainability concerns in delivering both construction and IT projects have come to the fore in advanced economies. Yet, developing countries have put economic development above meeting sustainability requirements (S. Banihashemi, et.al., 2017). The need for sustainable retirement benefits over a long period of time and reliable systems for management of members information has fuelled a huge demand for construction projects and implementation of improved IT systems hence environmental, social and 
governance (ESG) concerns being overshadowed. Project managers in Kenya are thus still lagging in integrating the concept of sustainability into core practices of managing projects.

Today every organization faces uncertain events that occur in different environments and with different characteristics and impacts (Alfredo Serpell et.al., 2015). These uncertain events can generate more or less severe consequences for the organization (Aven, 2011). In general, unexpected events occur in projects and may result in either positive or negative outcomes that are a deviation from the project plan. Positive outcomes are opportunities while negative outcomes generate a loss. Risk management focuses on the avoidance of loss from unexpected events (Williams, 1995).

Environmental Impact Assessment (EIA) is an essential legislative and scientific tool that provides quality assistance for decision-making towards sustainable development (Abdul-Sattar 2007). Abdul-Sattar (2007) studied reasons for the failure of EIA in developing countries and accounted for them as carrying out the EIA under limited cost, time, and available expertise. Sustainability assessment (SA) has emerged in recent years, its focus being more specifically on sustainability criteria in the assessment of policies, plans or projects. This is set to generate many new challenges for the EIA community, as governments struggle to reconcile the national policy and project decision-making processes with global agreements to reduce greenhouse gas emissions, while also dealing with the wider implications of climate change adaptation strategies. The effect of the theoretical awakening of EIA in the 1990s has been seen very clearly in the area of public participation, as would be expected given the influence in that new thinking of concepts of deliberative democracy, collaborative rationality and environmental justice (Kariuki Muigua, 2012).

Pension Funds in Kenya engage in two main types of projects, namely building construction both residential and commercial and information technology (IT) systems implementation projects. Current project management practices of Kenyan Pension Funds do not always ensure project success that secure market rates of return on these investments. The main problem with projects management practices have always been mentioned as planning, project implementation, cost and time overruns and quality achievement. While, the key success indicators of projects management systems include completing project within the planned budget and duration, and within the required quality, safety, social and environmental limits. With a focus on sustainability, a look into the triple bottom line concept will also be a measure of project performance. As the pension schemes are also expected to continue to invest in alternative assets given the broadening of the allowable investment categories and to take advantage of the public infrastructural projects under the big four agenda (RBA, 2021), it becomes paramount to implement sustainable project management practices for performance of the pension funds projects.

The primary objective of this study is therefore to determine the influence of impact assessment for sustainable project management to pension funds projects performance in Kenya.

\subsection{Literature Review}

There is an increasing swell from society demanding a more environmentally responsible approach in all project activities. There is increasing pressure to include a sustainable element in project management approaches (Silvius et al. 2012). From Silvius et al. (2012) point of view, projects are short term oriented while the sustainable attitude is long term oriented. Projects are results based while sustainable development is oriented on the whole life cycle of some economic activity.

Implementation of sustainability in project management will therefore include, a) changes in project management methods and tools, b) focus on a holistic approach to sustainability in changing projectoriented organization's top management attitude and c) change of the project culture in organization.

According to M.K Shad et.al. (2019), the sustainability approaches adopted by any industry or sector to which they belong must include the three dimensions of sustainability collectively termed the triple bottom line (3BL) - economic, social and environmental. The economic dimension of the 3BL refers to economic prosperity, profit making, attaining competitive advantage and sustaining the overall economic value of the business. The environmental sustainability includes factors relating to the environmental quality such as climate change, global warming, pollution and depletion of ozone layer. The social dimension includes the 
issues related to social progress such as health and safety, community well-being, employment opportunities, charity, and organisational behaviour (Aras et al., 2018).

The 3BL therefore suggests the interface of the economic, environmental and social performance of an enterprise (Carter and Rogers, 2008). The enterprise, in this case the pension funds should engross in such activities that not only improve economic, environmental and social performance but which also affect positively the long-term competitive advantage and sustainable development of the pension fund returns to its members.

For pension funds to effectively focus on sustainability, they need to ensure that the business is able to manage the business risk while meeting the members expectations. The schemes that seek to perform their businesses in socially responsible and holistic manner should attempt to put in place sustainability management framework that dominate in predicting the organisational performance (Maletit et al., 2018). This therefore includes adoption of sustainable project management practices as identified in the literature resources.

\subsection{Theoretical Framework}

This study hypothesises that to enhance projects performance, the pension funds need to have sustainable project management practices. Three theories were identified in support of this, namely: Stakeholder's theory, triple bottom line theory and risk management.

\subsubsection{Stakeholder Theory}

The essence of stakeholder theory is based on the general belief that the stakeholders are considered as an asset of an organisation and managers have to satisfy them (Zahid and Ghazali, 2017). All stakeholders such as shareholders, managers, employees, creditors, suppliers, customers, government agencies and local community can have interest in a business activities, objectives and behaviour (Aziz et al., 2015). The satisfaction of multiple stakeholders increases the goodwill of an organisation. The organisation can maintain its status and reputation in society, which ultimately increases their value.

The reporting on economic, environmental and social aspects determine that it accomplishes its part of the contract and that its activities match with the value systems of society and the environment. This can ensure regulatory compliance that would oblige the strategic requirements of an organisation. In the context of the stakeholder theory, it is established that the effective risk management and sustainable project management practices increase the pension funds projects economic value.

\subsubsection{Triple Bottom Line Theory}

The triple bottom line was introduced in 1997 which explores three main issues related to our study. Figure 1 represents the environmental responsibility (planet), economic responsibility (profit) and social responsibility (people). Corporate social responsibility ensures that these ideas of people, planet, and profit give a foundation for business. Therefore, a socially responsible country must consider environmental protection and well-being of society which leads to healthy financial performance of the business (Elkington, J., 1997). One is the traditional measure of corporate profit-the "bottom line" of the profit and loss account. The second is the bottom line of a company's "people account" a measure in some shape or form of how socially responsible an organization has been throughout its operations. The third is the bottom line of the company's "Planet" account-a measure of how environmentally responsible it has been. The triple bottom line (3BL) thus consists of three Ps: profit, people, and the planet. It aims to measure the financial, social and environmental performance of the corporation over a period. Only a company that produces a $3 \mathrm{BL}$ is taking account of the full cost involved in doing business. 


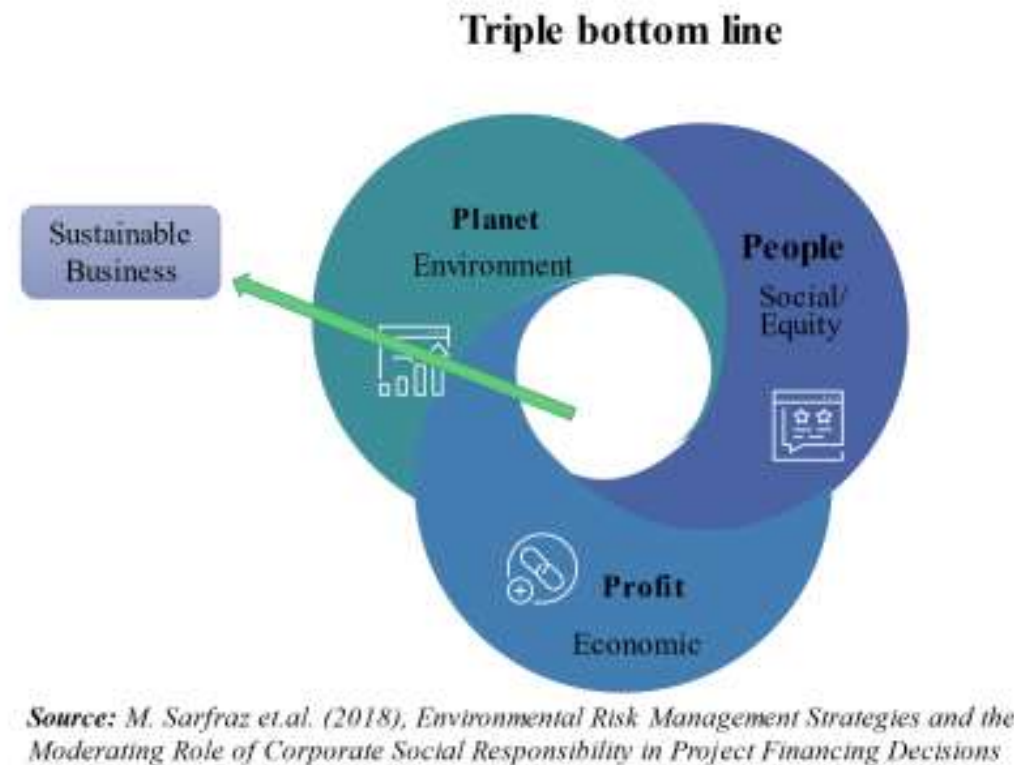

Figure 1: Triple bottom line

\subsubsection{Risk management Theory}

Risk management is a process that takes place during all phases of the project life. The objectives of risk management are to increase the probability and impact of positive events and decrease the probability and impact of negative events for the project (PMI, 2010). Since the risks exist from the moment a project is conceived, there should be a conscious choice of risks to identify and pursue effective management during the life of the project.

In construction projects, risks can seriously affect its main objectives: time, cost, scope and quality, which can mean an additional cost and hence a low rate of return on the investment for the customer and a loss of profit for the contractor, in addition to other consequences. Among the techniques used to identify the risks are the brainstorming, checklist; sensitivity analysis and risk register (Goh et. al., 2013), also indicating that qualitative methods for risk assessment are much more used than quantitative or semi-quantitative methods.

\subsection{Research methodology}

This study was based on a comprehensive literature review of the various project management sustainability practices that influence project performance. Secondary data of various academic journals, contributions by various industry experts, professionals and regulatory bodies was mainly used in the desk review done. The subject matter of focus was sustainable project management that contributes to project performance with a specific study on pension funds projects in Kenya.

Considering this was a desk review, content analysis was beneficial in allowing the researcher to comprehensively review the journal articles in identifying the sustainable project management practices. From the literature review, it was evident that the sustainable project management will influence pension funds project performance including deliberate focus on sustainability goals and environment and social impact assessment.

\subsection{Research outcomes}

This study hypothesised that to enhance projects performance, the pension funds need to implement sustainable project management while focusing on the regulatory framework as a moderating variable.

\subsection{Sustainable project management}

Sustainability is grabbing the attention of government, practitioners, corporations, research communities, and regulatory bodies worldwide. In Malaysia, the concept of corporate sustainability is still of a voluntary nature (Zahid and Ghazali, 2017). However, looking at its importance, many Malaysian organisations 
through various plans, toolkits, guidelines, programs, policies etc., are involved actively in promoting sustainability. The Malaysian government has addressed its expectations on the compliance of corporate sustainability in several chapters of its current developmental plan of (2016-2020).

This study hypothesised that to enhance projects performance, the pension funds need to implement sustainable project management, specifically, environmental and social impact assessments with a focus on sustainability goals.

Projects are implemented to achieve a certain goal and selected objectives (Kivila et.al., 2017). In addition to the iron triangle objectives of scope, time, and cost, companies are increasingly concerned with a project's broader benefits and value (Silvius and Schipper, 2014). The strategic value of a project can be considered in terms of various social, ecological, and economic dimensions (Martinsuo and Killen, 2014) that are featured in sustainability. Benefits, value, and value creation may imply different things to the project contractor and the customer (Winter and Szczepanek, 2008) and appear differently during the different phases of the project's and the product's life cycle (Labuschagne and Brent, 2005), thus making the specification of project goals very challenging.

Sustainability in delivery projects can be viewed from different perspectives. Previous research has recognized four aspects of sustainability: product related, process related, organization, and people (Marcelino-Sadaba et al., 2015). Sustainability in project business concerns the process of the project delivery and the project deliverable (Gareis et al., 2013). In this study, the focus is on sustainable project management, that is, the project delivery side of sustainability. However, as the project deliverable is designed and implemented during project delivery, the project deliverable is also affected by sustainable project management.

Sustainable project management implies the use of practices that ensure social, ecological, and profitable delivery of the project so that the project deliverable is socially and environmentally acceptable throughout its life cycle (Silvius and Schipper, 2014). Sustainable project management involves and builds on stakeholder cooperation (Eskerod and Huemann, 2013), includes life cycle thinking (Labuschagne and Brent, 2005), and balances the three dimensions of sustainability (Silvius and Schipper, 2014, building on Elkington 1997). Klakegg (2009) suggested several reasons for the lack of sustainability in project management: conflict of interest, lack of commitment from key stakeholders, low economic benefits of sustainability compared to the required investment and changing conditions.

Various practices have been introduced to characterize sustainable project management. For example, Klakegg (2009) proposed clearly expressing sustainability as an evaluation criterion, holistic planning with sustainability included in the bottom line, reviewing relevant stakeholders' concerns and expectations, and ensuring flexibility of the delivery of the project to increase the value of the investment. Saving energy during the construction phase and during the life cycle of a building helps cut greenhouse gas emissions (Zhang et al., 2015). Considering the life cycle perspective in road construction projects helps reduce the greenhouse gas emissions involved (Barandica et al., 2013). Sustainability and project management should be integrated (Marcelino-Sadaba et al., 2015) to make sure that project management is updated and ready to face global sustainability-related problems.

In the study conducted on a large infrastructure project by Kivila et.al., (2017), empirical findings showed that the social dimension of sustainability in the case project was evident everywhere. The project was highly political, the inhabitants were first worried and then curious about the project, the alliance model eased interaction between the project actors, and safety and public image were key performance indicators. As the project location was very challenging in terms of the environmental effects, the environmental issues were highlighted through regulations and in the project plan and implemented through grass roots task and work instructions. The economic dimension of sustainability was linked to the bonuses and sanctions of the alliance model (i.e., the financial incentive model) and was strongly affected by actions for the environmental and social dimensions.

Among the key results in this study is the identification of dependencies between the environmental, social, and economic dimensions of sustainability, particularly in alliance projects with risk and benefit-sharing schemes. The balancing of the three dimensions supports previous research (Silvius and Schipper, 2014), but 
Kivila et.al., (2017) findings contribute to the literature by showing how the alliance contract can enhance this balance. Previous researchers emphasized the environment dimension over the social and economic dimensions of sustainability. The nature of social sustainability, in particular, is less well understood (EdumFotwe and Price, 2009).

The findings by Kivila et.al., (2017) indicate that certain project conditions increase the pressure to move the focus from environmental issues (which are more regulated and, thus, self-evidently implemented) to the social dimension of sustainability (which are not necessarily regulated but attract public attention), or at least to consider the two dimensions equivalent. In the case project by Kivila et.al., (2017), the central location in the city, publicity about the project, and the high number of stakeholders involved may have increased the importance of social sustainability. The findings also showed that as environmental and social issues were included in the shared incentive model of the alliance contract, all stakeholders had a financial incentive to carry out and manage the project in a sustainable way.

\subsection{Impact assessment and framework for sustainable development of projects}

Environmental Impact Assessment (EIA) ${ }^{1}$ and Social Impact Assessment (SIA) ${ }^{2}$ are widely used tools to assess the impacts at an early stage in project planning and design (Morimoto 2013). An EIA is an essential legislative and scientific tool that provides quality assistance for decision-making towards sustainable development (Abdul-Sattar 2007). Though many developing countries have a system of EIA, developers greatly manipulate the process because of corruption in collusion with bureaucrats (Kumar and Katoch 2014). Abdul-Sattar (2007) studied reasons for the failure of EIA in developing countries and accounted for them as carrying out the EIA under limited cost, time, and available expertise. Another reason which is generally not associated with the developed countries is the wrong perception of EIA in developing countries whereby in the beginning the EIA content is under great attention, but eventually, interest decreases by the time of implementation (Shaktawat and Vadhera, 2020).

As Friedmann (1998) acknowledges, every jurisdiction that operates EIA procedures does so in the context of its own culture of decision-making, its own legislative background and its own environmental priorities. To understand EIA and to assess its effectiveness in terms of its procedural role or substantive purpose can therefore only be accomplished on the basis of an understanding of its operation within specific jurisdictions and the culture of decision-making that exists there.

In Kenya, the goal of an EIA is to ensure that decisions on proposed projects and activities are environmentally sustainable. The projects to be subjected to EIA are specified in the Second Schedule of the Environmental Management and Co-ordination Act, 1999 (EMCA) of which the construction projects undertaken by pension funds fall under. Impact assessment practice around the world is dominated by its use at the project level, with particular emphasis on major projects (Wood 2003) ${ }^{3}$.

Under the umbrella of EIA, a number of specific forms have developed since the 1970s with some emerging in recent years, these include: social impact assessment (SIA), health impact assessment (HIA), strategic environmental assessment (SEA), regulatory impact assessment (RIA), human rights impact assessment, cultural impact assessment, post-disaster impact assessment and climate change impact assessment.

To some extent, each tends to have arisen through some level of dissatisfaction with EIA as it has been practised. SIA, for example, developed strongly in the late 1970s and 1980s because EIA, especially in the USA, was considered to have a strong biophysical emphasis, often neglecting social impacts (Taylor et al. $2004)^{4}$. More recently HIA has emerged as a vigorous form of impact assessment, responding to a sense

\footnotetext{
${ }^{1}$ EIA comes in 1969 from section 102(2) of the National Environmental Policy Act (NEPA), USA. After the implementation of NEPA in 1969, countries like Australia, Canada, and New Zealand adopted EIA during the mid-1970s. Since then, it has been instituted in the jurisdictions of many developed and devel-oping countries (Robinson 1992). For example: In India, EIA came into existence in around 1978-1979, but it was made mandatory only in 1994 under the Environmental Protection Act of 1986, for 30 categories of developmental projects among which hydropower is a significant one.

${ }^{2}$ SIA is federally mandated and performed in conjunction with EIA to address any potential social issues caused by the proposed project (Tilt et al. 2009).

${ }^{3}$ Wood, C., 2003. Environmental impact assessment: a comparative review. 2nd ed. Harlow: Prentice Hall.

${ }^{4}$ Taylor, C.N., Bryan, C.H., and Goodrich, C.G., 2004. Social assessment: theory, process and techniques. 3rd ed. Middleton, WI: Social Ecology Press
} 
among many public health professionals that EIA did not adequately address project impacts on community and individual health (National Academy of Sciences 2011).

SEA has been vigorously promoted as a way to extend impact assessment to higher level decision-making at policy, programme and plan levels, a reaction to the project orientation of most EIA applications (Sadler 2011) ${ }^{6}$. A related approach, sustainability assessment (SA), has emerged in recent years, its focus being more specifically on sustainability criteria in the assessment of policies, plans or projects. The lastmentioned looks set to generate many new challenges for the EIA community, as governments struggle to reconcile the national policy and project decision-making processes with global agreements to reduce greenhouse gas emissions, while also dealing with the wider implications of climate change adaptation strategies.

The effect of the theoretical awakening of EIA in the 1990s has been seen very clearly in the area of public participation, as would be expected given the influence in that new thinking of concepts of deliberative democracy, collaborative rationality and environmental justice. Public participation ${ }^{7}$ is therefore at the centre of EIA (Kariuki Muigua, 2012).

According to Weston, $(2010)^{8}$ the impact assessment community has the opportunity to shift EIA thinking away from the licensing stage and closer to the critical decisions within organizations. That is, EIA should be integral to project development and design processes, not left to the final legal step before project implementation. This would reduce the emphasis on compliance-oriented EIA, allowing impact assessors to work more constructively with proponents and stakeholders to develop processes that meet the needs of all parties, and in so doing result in projects that are consistent with the environmental and social aspirations of local communities. This will greatly contribute towards sustainable project management practices.

A framework for sustainable project management involves identifying issues, gaps to consider and to assess the project's sustainability performance. A robust assessment in terms of the social, environmental and economic impacts is essential for successful implementation of a sustainable project.

\subsection{Regulatory Framework}

RBA through the retirement benefits regulations sets the statutory investment limits. A review of the literature showed that all categories of investment were within the statutory investment limits provided in the Retirement Benefits Regulations. The immovable property limit is given as 30 percent, but only 17.96 percent of the pensions industry value had investment in it, hence falling within the statutory investment limit.

Regulatory framework is used to check the effects of regulatory framework on the project performance of the pension funds projects in Kenya. RBA has been ably mandated by the Kenyan government through an act of Parliament to set the regulations and policies that govern the pension industry in Kenya. This is to protect the interests of members and sponsors of retirement benefits sector and promote the development of the retirement benefits sector.

According to OECD Network of Economic Regulators, (2021), regulatory bodies are playing an active role in promoting the transition towards a sustainable global economy. They also operate in a context of increasing complexity, technological disruption and constrained resources, while having to manage uncertainty and create enjoyable, prosperous and safe places to live, work and do business. The transition towards a sustainable global economy includes sustainable project management practices that align with the

\footnotetext{
${ }^{5}$ National Academy of Sciences, 2011. Improving health in the United States: the role of health impact assessment. Washington, DC: The National Academies Press

${ }^{6}$ Sadler, B., et al., 2011. Taking stock of SEA. In: B. Sadler, ed. Handbook of strategic environmental assessment. London: Earthscan, 1-18.

${ }^{7}$ O'Faircheallaigh (2010) suggests a three-fold classification of the purposes of public participation in EIA - obtaining public input into decisions taken separately by decision-makers, providing some degree of public sharing of decision-making, and altering the structures and power relationships of decision-making.

${ }^{8}$ Weston, J., 2010. EIA theories - all Chinese whispers and no critical theory. Journal of Environmental Assessment Policy and Management, 12 (4), 357-374.
} 
social, environmental and economic goals. RBA is therefore at the forefront of providing regulatory guidelines in relation to the sustainability agenda that will positively influence pension funds' investments.

\subsection{Discussion}

Pension funds undertake construction projects under the immovable property asset class ${ }^{9}$ to make measurable improvements that will contribute to the investment objective of maximising the long-term return on investments and minimising short-term volatility and anticipated liquidity needs while taking cognisance of the nature, size, type, and maturity profile of the respective Schemes. PRINCE2 (2017) states that all projects must have documented business justification, which is a precursor to a sustainable project. This sets out not only the reason for the project, but also confirms the projects is viable (able to deliver the investment property), desirable (balance of costs, benefits and risks) and achievable (whether use of the investment property is likely to result in envisaged outcomes and resulting benefits).

Pension funds construction of commercial and/or residential projects for rent or sale focuses on diversification of the Funds asset classes to meet the objective of optimising returns to their members. These projects deliver output (complete investment property), the use of which result in changes in the pension funds' performance. These changes then create outcomes (rental income or sales) which allow the pension funds to realise the benefits (optimal returns to members) that are set out in the business justification for the projects.

Project management sustainability is therefore supported by continuous business justification which is usually documented in a business case. The benefits specified for providing optimal returns to members should therefore be aligned with funds and other stakeholders' objectives and be realised.

Pension funds construction projects not only involve the risk of cost overruns but affecting the ecosystems and related environmental impacts based on the type of property investment undertaken. There is need to factor sustainable environmental goals that address issues such as climate change effects ensuring strategies to address these are considered in the construction projects. Includes, renewable energy production to support the energy needs of the investment property since climate change in unavoidable. This will ensure optimal returns by minimising costs and hence support social dimension of sustainability by meeting the energy needs of the customers. The economic dimension of sustainability will also be met through supply of cost-efficient energy needs and consequently supporting environmental sustainability goals by addressing pollution and emission of greenhouse gases concerns.

Pension funds projects are seen as public investment projects because they concern the interests of many members whose objective is to gain an optimal return on their investment for a secured retirement. There is therefore a focus on project sustainability practices. Coordinating and understanding multiple stakeholder viewpoints is part of social sustainability. Managers need to understand that these viewpoints are as important as ecological issues that are the traditional focus when sustainability is considered. They need to consider practices for project sustainability governance, as the involvement of the pension funds, regulators and other stakeholders toward sustainability needs to be specified and agreed. In pension funds projects, intensive and collaborative planning is beneficial not only for project's deliverable but also for enabling innovativeness and sustainable practices throughout the implementation of the project.

\subsection{Recommendations and Conclusions}

It was evident from the literature that for sustainability of projects, the ability to quickly react to change has become paramount to the success of an organization. This applies directly to the pension funds when implementing construction projects. Projects have become the catalysts by which pension funds achieve their strategies, and the ability to manage projects effectively has become a required competency. Sustainable project management practices such as project risk management can be achieved based on understanding the risks related to the project and their interactions with Industry 4.0 technologies (Santosh et al., 2019).

\footnotetext{
${ }^{9}$ A specific area/type of investment e.g., domestic listed equities, property, offshore, fixed income, etc.
} 
There is need to embed sustainability in the construction contract and the performance indicators of the projects, drawing attention to good sustainability-oriented plans (Jesse and Lauri (2017). Large infrastructure projects involving multiple stakeholder interests are susceptible to public and political debate. Pension funds in Kenya can find themselves in this space and therefore, intense planning is required in the early phase of the project in proactively resolving the public's social and environmental concerns and eventually promoting the project's economic success.

The study proposes a pool of sustainable project management practices for project performance of pension funds construction projects in Kenya. The findings revealed novel insights related to sustainable project management practices that contribute to project cost efficiency, completion of the projects within schedule, as per quality standards and within scope.

It emerged that the regulatory environment is largely supportive of sustainability initiatives that support the people (social), planet (environmental), profit (economic) objectives, and therefore contributing towards sustainable project management practices. These further contribute towards the triple bottom line agenda, which focuses on sustainable business practices and influencing the achievement of the iron triangle objectives.

The study will be beneficial to project management practitioners across various sectors and industries to appreciate a holistic project management practice that focus on sustainability towards achieving project performance in pension funds projects. The explored sustainable project management practices, that is, sustainability goals and impact assessment (environmental and social), were found to positively influence project performance which would then be expected to be the same in pension funds projects in Kenya. This in turn will assist the pension funds in achieving their targets of providing sustainable returns to their members through the investment opportunities undertaken in the construction space under the immovable property asset class.

\section{References}

1. Abdul-Sattar, N. (2007), "Comparative analysis of the EIA system of developed and developing countries: Cases of hydroelectric power plants." Gothenburg: Environmental System Analysis, Chalmers Univer-sity of Technology.

2. Abidin, N.Z., Pasquire, C.L., (2007). Revolutionize value management: a mode towards sustainability. Int. J. Proj. Manag. 25, 275-282.

3. Alfredo Serpell, Ferrada. X., Rubio, L. and Arauzo, S. (2015), "Evaluating risk management practices in construction organizations." Published by Elsevier Ltd. Procedia - Social and Behavioural Sciences 194 (2015) 201-210

4. Aras, G., Tezcan, N., Kutlu Furtuna, 0., 2018. Multidimensional comprehensive corporate sustainability performance evaluation model: evidence from an emerging market banking sector. J. Clean. Prod. 185, 600-609.

5. Aven. T. (2011). On the new ISO guide on risk management terminology. Reliability Engineering and System Safety. 96: 719-726.

6. Aziz, NA.A., Manab, NA., Othman, S.N., (2015), "Exploring the perspectives of corporate governance and theories on sustainability risk management (SRM)." Asian Econ. Financ. Rev. 5 (10), 1148 .

7. Banihashemi, S., Hosseini, M.R., Golizadeh, H. and Sankaran, S. (2017), "Critical Success factors (CSFs) for integration of sustainability into construction project management practices in developing countries." International Journal of Project Management

8. Carter, C.R., Rogers, D.S., 2008. A framework of sustainable supply chain manage-ment: moving toward new theory. Int. J. Phys. Distrib. Logist. Manag. 38 (5), 360-387.

9. Chang, R.-d., Soebarto, V., Zhao, Z.-y., Zillante, G., (2016). Facilitating the transition to sustainable construction: China's policies. J. Clean. Prod. 13 I, 534-544.

10. Dobrovolskiene, N., Tamosiiiniene, R., (2016). Sustainability-oriented financial resource allocation in a project portfolio through multi-criteria decision-making. Sustainability $8,485$. 
11. Du Plessis, C., (2007). A strategic framework for sustainable construction in developing countries. Constr. Manag. Econ. 25, 67-76.

12. Elkington, J. (1997), "Cannibals With Folks: The Triple Bottom Line of 21st Century Business"; Wiley: Hoboken, NJ, USA, 1997.

13. Eskerod, P., Huemann, M., (2013). Sustainable development and project stakeholder management: what standards say. Int. J. Manag. Proj. Bus. 6 (1), 36-50.

14. Gareis, R., Huemann, M., Martinuzzi, R.-A., Weninger, C., Sedlacko, M., (2013). Project Management \& Sustainable Development Principles. Project Management Institute, Newton Square, PA.

15. Huemann, M., Ringhofer, C., (2016). Challenge or potential? Risk identification in the context of sustainable development. In: Bodea, C., Purnus, A., Hueman, M., Hajdu, M. (Eds.), Managing Project Risks for Competitive Advantage in Changing Business Environments. IGI Global Publishing, pp. 87-105.

16. Kariuki Muigua (2018) Environmental Impact Assessment (EIA) in Kenya

17. Kivila, J., Martinsuo, M, and Vuorinen, L. (2017), "Sustainable project management through project control in infrastructure projects", International Journal of Project Management, DOI: https:/ /doi.org/10.1 Ol 6/j.iiproman.2017.02.009

18. Kumar, D., \& Katoch, S. S. (2014), "Sustainability indicators for run of the river (RoR) hydropower projects in hydro rich regions of India." Renewable and Sustainable Energy Reviews, 35, 101-108.

19. Labuschagne, C., Brent, A.C., (2005), "Sustainable Project Life Cycle Management: The need to integrate life cycles in the manufacturing sector." Int. J. Proj. Manag. 23, 159-168. doi: 10.1016/j.ijproman.2004.06.003

20. Maletit, M., Maletit, D., Gomistek, B., (2018), "The role of contingency factors on the relationship between sustainability practices and organizational performance.” J. Clean. Prod. 171, 423-433.

21. Marcelino-Sadaba, S., Gonzalez-Jaen, L.F., Perez-Ezcurdia, A., (2015), "Using project management as a way to sustainability. From a comprehensive review to a framework definition." J. Clean. Prod. 99, 1-16. doi:10.1016/j.jclepro.2015.03.020

22. Martinsuo, M., Killen, C.P., (2014), "Value management in project portfolios: Identifying and assessing strategic value.” Proj. Manag. J. 45, 56--70. doi:10.1002/pmj

23. Olawumi, T.O., Chan, D.W.M., (2018). A scientometric review of global research on sustainability and sustainable development. J. Clean. Prod. 183, 231-250.

24. Ortiz, 0., Castells, F., Sonnemann, G., (2009). Sustainability in the construction industry: a review of recent developments based on LCA. Constr. Build. Mater. 23, 28-39.

25. [PRINCE2®] Axelos Limited. (2017), Managing Successful Projects with PRINCE2® Axelos Global Best Practice

26. Project Management Institute, (2010), "Managing Project Risk: In a Guide to the Project Management for (PMBOK Guide)," 5th Ed.; Global Standard; Project Management Institute: Newtown Square, PA, USA, 2010; pp. 234-266.

27. PMI (Project Management Institute), (2013), A Guide to the Project Management Body of Knowledge (PMBOK Guide) (Newton Square, PA).

28. PMI - Project Management Institute (2017), "A Guide to the Project Management Body of Knowledge", (PMBOK® GUIDE) 6th Edition

29. Retirement Benefits Authority (RBA), 2020. "Retirement Benefits Industry Report for December 2020", Research and Strategy Department.

30. Santosh, B.R., Prathamesh, R.P. and Suraj, R. (2019), "Development of Project Risk Management framework based on Industry 4.0 technologies", Emerald Insight, available at DOI: https://doi.org/10.1108/BIJ-03-2019-0123

31. Savitz, A.W., (2006). The Triple-bottom Line: How Today's Best-run Companies are Achieving Economic, Social and Environmental Success - And How You Can Too. John Willey \& Sons, San Francisco. 
32. Sarfraz, M., Qun, W., Hui, L. and Abdullah, M.I. (2018), "Environmental Risk Management Strategies and the Moderating Role of Corporate Social Responsibility in Project Financing Decisions." Sustainability 2018, 10, 2771

33. Shad, M.K., Lai, F.W., Fatt, C.L. and Klemes, J.J. (2019), "Integrating sustainability reporting into enterprise risk management and its relationship with business performance: A conceptual framework." Journal of Cleaner Production 208 (2019) 415-425

34. Shaktawat, A. and Vadhera, S. (2020), "Risk management of hydropower projects for sustainable development: a review" Environment, Development and Sustainability

35. Silvius, M.G., van den Brink, M.J., Schipper, M.R., Planko, M.J., Kohler, M.A., (2012). Sustainability in Project Management. Gower Publishing, Ltd.

36. Silvius, A.J.G., Schipper, R., (2014). Sustainability in project management: a literature review and impact analysis. Soc. Bus. 4 (I).

37. Silvius, A.J.G., Schipper, R., (2015). Developing a maturity model for assessing sustainable project management. J. Mod. Proj. Manag. 3 (1), 16-27.

38. Silvius, A.J.G., Kampinga, M., Paniagua, S., Mooi, H., (2017). Considering sustainability in project management decision making; an investigation using Q-methodology. Int. J. Proj. Manag. 35 (6), 1133-1150.

39. WCED, (1987). Our Common Future. Oxford University Press, Oxford.

40. Weninger, C., Huemann, M., (2013). Project initiation: investment analysis for sustainable development. In: Silvius, A.J.G., Tharp, J. (Eds.), Sustainability Integration for Effective Project Management. IGI Global Publishing.

41. Winter, M., Szczepanek, T., 2008. Projects and programmes as value creation processes: A new perspective and some practical implications. Int. J. Proj. Manag. 26, 95-103. doi:10.1016/j.ijproman.2007.08.015

42. Zahid, M., and Ghazali, Z., (2017), "Corporate sustainability practices and business's financial performance: the driving force of integrated management system." Glob. Bus. Manag. Res. 9 (ls), 479.

43. Zhang, X., Wu, Y., Shen, L., Skitrnore, M., (2014). A prototype system dynamic model for assessing the sustainability of construction projects. Int. J. Proj. Manag. 32, 66-76. 